\section{Kidney \\ Blood Pressure Research}

\title{
Reduced Erythrocyte Survival in Uremic Patients Under Hemodialysis or Peritoneal Dialysis
}

\author{
Rosi Bissinger ${ }^{a} \quad$ Ferruh Artunc $^{b} \quad$ Syed M. Qadric Florian Lang ${ }^{\mathrm{a}, \mathrm{d}}$

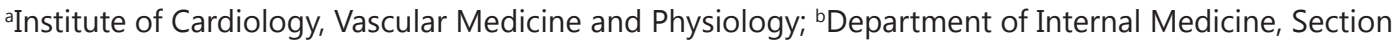 \\ of Nephrology, University of Tuebingen, Tuebingen, Germany; 'Department of Pathology and Molecular \\ Medicine, McMaster University, Hamilton, ON, Canada; ${ }^{\mathrm{d} D e p a r t m e n t}$ of Molecular Medicine II, Medical \\ Faculty, Heinrich Heine University, Düsseldorf, Germany
}

\section{Key Words}

Anemia $•$ End-stage renal disease $・$ Eryptosis $\bullet$ Hemodialysis $\bullet$ Peritoneal dialysis

\begin{abstract}
Background/Aims: Recent observations in end-stage renal disease (ESRD)-patients on hemodialysis revealed that anemia is, in part, due to stimulated suicidal erythrocyte death or eryptosis leading to accelerated clearance of circulating erythrocytes. The present study explored whether eryptosis is similarly enhanced in patients on peritoneal dialysis (PD). Methods: Measurements were made in freshly drawn erythrocytes from healthy volunteers $(n=38)$, and ESRD patients on hemodialysis (HD; $n=18)$ or on PD $(n=22)$. Both, HD patients and PD patients suffered from anemia despite increased reticulocyte numbers. Results: The percentage of phosphatidylserine-exposing erythrocytes was significantly higher in HD patients than in healthy volunteers and significantly higher in PD patients than in healthy volunteers and HD patients. In PD patients, the percentage of phosphatidylserine-exposing erythrocytes was positively correlated with dialysis volume. The increase in phosphatidylserine exposure was in both, HD and PD patients, paralleled by increase of reactive oxygen species and ceramide abundance. In both, HD and PD patients, a positive correlation was observed between the percentage of phosphatidylserine-exposing erythrocytes and both, erythropoietin dosage and the percentage of reticulocytes. Conclusions: Similar to HD patients, PD patients suffer from enhanced eryptosis, which is paralleled by oxidative stress and enhanced ceramide abundance contributing to the anemia of uremic patients.
\end{abstract}

R. Bissinger and F. Artunc contributed equally to this work and thus share first authorship. 


\section{Kidney Blood Pressure Research}

\section{Introduction}

In end-stage renal disease (ESRD), the decreased renal erythropoietin (EPO) release leads to a subsequent decrease of erythropoiesis [1-9] and thus to anemia [10,11]. In ESRD, erythropoiesis is further compromised by iron deficiency [4, 6, 12-15].

As shown in patients on hemodialysis (HD) [16-18], anemia in ESRD results in part from stimulation of suicidal erythrocyte death or eryptosis, leading to accelerated clearance of circulating erythrocytes [19]. Eryptosis is characterized by cell shrinkage and cell membrane scrambling with phosphatidylserine exposure at the erythrocyte surface [20, 21]. Defective and aged erythrocytes are cleared from circulating blood [20, 22]. Thus, accelerated erythrocyte death may lead to anemia [20]. Cellular mechanisms involved in the triggering of eryptosis include increase of cytosolic $\mathrm{Ca}^{2+}$ concentration $\left(\left[\mathrm{Ca}^{2+}\right]_{\mathrm{i}}\right)$, oxidative stress and ceramide formation $[20,21,23]$. The enhanced eryptosis in patients on HD was, at least in part, due to a plasma borne component increasing $\left[\mathrm{Ca}^{2+}\right]_{i}$, reactive oxygen species (ROS), and ceramide abundance [18].

Peritoneal dialysis (PD) is an equivalent yet under-utilised modality of renal replacement therapy with similar outcome compared to HD. The prevalence and severity of renal anemia tends to be lower in PD patients [24] and was associated with a lower EPO dose to maintain similar $\mathrm{Hb}$ values compared to HD patients [25]. However, the relevance of eryptosis in the aggravation of renal anemia in PD patients remained illdefined. The present study explored, whether eryptosis similarly contributes to anemia in patients on peritoneal dialysis (PD) and whether the rate and mechanisms of eryptosis differ between HD and PD.

\section{Patients and Methods}

\section{Patients, erythrocytes and treatments}

Eighteen patients (11 male, 7 female) on hemodialysis (HD) and 22 patients (11 male, 11 female) on peritoneal dialysis (PD) have been enrolled in the study. Clinical details of the patients are compiled in Table 1. The patients were recruited from the Division of Nephrology at the Department of Internal Medicine, University Hospital Tübingen. The blood from HD patients was drawn prior to a 4-h hemodialysis session on a Fresenius 5008 dialysis machine. Blood from PD patients was drawn at a regular outpatient visit between 9 and 12 am. Blood samples for HD and PD patients as well as blood from healthy volunteers were drawn on the same day. The study was approved by the ethics committee of the University of Tübingen $(184 / 2003 \mathrm{~V})$ and has been executed in accordance with the Declaration of Helsinki. Both, volunteers and patients provided informed written consent. Eryptosis measurements were made in freshly isolated erythrocytes from the three groups HD, PD and healthy volunteers in parallel. For all measurements using FACS analysis, 50,000 cells were counted.

\section{Annexin V-binding and forward scatter}

In order to determine annexin-V-binding, $2 \mu \mathrm{l}$ of freshly drawn blood were mixed in $500 \mu$ l Ringer solution containing $5 \mathrm{mM} \mathrm{CaCl}_{2}$, subsequently stained with Annexin-V-FITC (1:200 dilution; ImmunoTools, Friesoythe, Germany) in Ringer solution containing $5 \mathrm{mM} \mathrm{CaCl}_{2}$ at $37^{\circ} \mathrm{C}$ for $15 \mathrm{~min}$ under protection from light. The annexin $\mathrm{V}$ abundance at the erythrocyte surface was subsequently determined on a FACS Calibur (BD, Heidelberg, Germany). Annexin-V-binding was measured with an excitation wavelength of $488 \mathrm{~nm}$ and an emission wavelength of $530 \mathrm{~nm}$. A marker (M1) was placed to set an arbitrary threshold between annexinV-binding cells and control cells. The same threshold was used for healthy erythrocytes and erythrocytes from patients on hemodialysis and peritoneal dialysis. A dot plot of forward scatter (FSC) vs. side scatter (SSC) was set to linear scale for both parameters.

Intracellular $\mathrm{Ca}^{2+}$

In order to quantify intracellular $\mathrm{Ca}^{2+}, 2 \mu \mathrm{l}$ freshly drawn blood was mixed in $500 \mu$ l Ringer solution containing $5 \mathrm{mM} \mathrm{CaCl}_{2}$, stained with Fluo-3/AM (5 $\mu \mathrm{M}$; Biotium, Hayward, USA) and incubated at $37^{\circ} \mathrm{C}$ for $30 \mathrm{~min}$. Then $\mathrm{Ca}^{2+}$-dependent fluorescence intensity was measured in FL-1 channel with an excitation 


\section{Kidney Blood Pressure Research}

Table 1. Characteristics of the patients. Values are given as median with interquartile range (IQR, $25^{\text {th }}-75^{\text {th }}$ percentile).

\begin{tabular}{|c|c|c|c|}
\hline & Hemodialysis & Peritoneal dialysis & P-value* \\
\hline Number and gender of patients & $18(110,7$ \% $)$ & $22\left(11 \jmath^{\lambda}, 11+\right)$ & 0.3023 \\
\hline Age & $\begin{array}{l}68.5(55.8 ; 76.5) \text { years } \\
\text { (range: } 47-79)\end{array}$ & $\begin{array}{l}49.0(38.8 ; 63.8) \text { years } \\
\quad \text { (range: } 31-87)\end{array}$ & $0.0077^{* *}$ \\
\hline Body mass index & $23.2(21.3 ; 28.8)$ & $24.6(21.1 ; 28.6)$ & 0.9892 \\
\hline Cause of CKD & $\begin{array}{c}\text { Diabetic-Hypertensive } \\
\text { nephropathy }(\mathrm{n}=5) \\
\text { Hypertension }(\mathrm{n}=3) \\
\text { Glomerulonephritis }(\mathrm{n}=1) \\
\text { Polycystic kidney disease }(\mathrm{n}=1) \\
\text { Other/unknown }(\mathrm{n}=8)\end{array}$ & $\begin{array}{l}\text { Diabetic nephropathy }(\mathrm{n}=1) \\
\text { Diabetic-Hypertensive } \\
\text { nephropathy }(\mathrm{n}=3) \\
\text { Hypertension }(\mathrm{n}=3) \\
\text { Glomerulonephritis }(\mathrm{n}=6) \\
\text { Polycystic kidney disease }(\mathrm{n}=3) \\
\text { Other/unknown }(\mathrm{n}=7)\end{array}$ & \\
\hline Time on dialysis (months) & $33.0(7.50 ; 78.0)$ & $20.0(12.75 ; 35.0)$ & 0.4611 \\
\hline Mode of dialysis & $\begin{array}{c}22 \% \mathrm{HD}, 78 \% \mathrm{HDF} \\
4 \text { hours; } 280-320 \mathrm{ml} / \mathrm{min}\end{array}$ & $\begin{array}{l}41 \% \text { CAPD, } 59 \% \text { APD } \\
\text { Median dialysate volume } 10.5 \mathrm{l} \\
(4.5 ; 11.2) ; \text { Median glucose } \\
\text { concentration } 2.03 \mathrm{~g} / \mathrm{l}(1.7 ; 2.3)\end{array}$ & \\
\hline ESA dose (I.U.) & $3125(401 ; 6000)$ & $4583(1114 ; 6579)$ & 0.3904 \\
\hline Plasma creatinine concentr. (mg/100 ml) & $6.75(5.12 ; 8.42)$ & $7.62(5.22 ; 9.95)$ & 0.4967 \\
\hline Plasma c-reactive protein $(\mathrm{mg} / 100 \mathrm{ml})$ & $1.15(0.42 ; 2.79)$ & $0.9(0.34 ; 2.14)$ & 0.4629 \\
\hline Leucocytes $(/ \mu \mathrm{l})$ & $7229(5544 ; 8638)$ & $8688(6580 ; 9001)$ & 0.1458 \\
\hline Plasma urea concentration $(\mathrm{mg} / 100 \mathrm{ml})$ & $104.3(74.9 ; 127.4)$ & $102.5(84.38 ; 124.7)$ & 0.8597 \\
\hline Plasma uric acid concentr. (mg/100 ml) & $6.55(5.38 ; 7.70)$ & $6.1(5.05 ; 6.69)$ & 0.3510 \\
\hline Plasma iron concentration $(\mu \mathrm{g} / 100 \mathrm{ml})$ & $53.75(40.50 ; 84.0)$ & $59.5(47.25 ; 89.63)$ & 0.5772 \\
\hline Plasma ferritin concentration $(\mu \mathrm{g} / 100 \mathrm{ml})$ & $44.5(24.5 ; 68.0)$ & $18.5(9.15 ; 41.13)$ & $0.0051^{* *}$ \\
\hline Transferrin $(\mathrm{mg} / 100 \mathrm{ml})$ & $168.3(138.6 ; 197.8)$ & $223(194.0 ; 245.6)$ & $0.0020^{* *}$ \\
\hline Transferrin saturation (\%) & $25.6(15.58 ; 33.7)$ & $19.1(15.58 ; 27.15)$ & 0.2369 \\
\hline \multicolumn{4}{|l|}{ Blood count } \\
\hline hematocrit & $31.31(27.2 ; 33.32)$ & $32.04(30.26 ; 34.91)$ & 0.2264 \\
\hline hemoglobin & $10.07(9.17 ; 11.22)$ & $10.89(10.16 ; 11.61)$ & 0.0794 \\
\hline reticulocytes (\%) & $2.66(1.95 ; 3.42)$ & $2.23(1.56 ; 3.29)$ & 0.5229 \\
\hline Erythropoietin/hemoglobin & $331.5(47.5 ; 540.0)$ & $429(98.5 ; 731.0)$ & 0.4213 \\
\hline Residual diuresis (ml/24 h) & $450(75 ; 1188)$ & $904.2(200 ; 1513)$ & 0.1237 \\
\hline $\begin{array}{l}\text { Concurrent medication (Dialysis specific } \\
\text { medication) }\end{array}$ & $\begin{array}{l}\text { beta-blockers ( } \mathrm{n}=13) \text {, AT-1 } \\
\text { blockers }(\mathrm{n}=5), \text { ACE- } \\
\text { inhibitors }(\mathrm{n}=5) \text {, calcium } \\
\text { antagonists }(\mathrm{n}=7), \\
\text { anticoagulants }(\mathrm{n}=5) \text {, loop } \\
\text { diuretics }(\mathrm{n}=11), \text { Vitamin } \mathrm{D} \\
(\mathrm{n}=18) \text {, phosphate binders } \\
(\mathrm{n}=14) \text {, antidepressants } \\
(\mathrm{n}=6), \text { proton-pump } \\
\text { inhibitors }(\mathrm{n}=10)\end{array}$ & $\begin{array}{l}\text { beta-blockers }(n=16) \text {, AT- } 1 \\
\text { blockers }(n=2), \text { ACE- } \\
\text { inhibitors }(n=9), \text { calcium } \\
\text { antagonists }(n=14), \\
\text { anticoagulants }(n=5) \text {, loop } \\
\text { diuretics }(n=19) \text {, Vitamin } D \\
(n=22) \text {, phosphate binders } \\
(n=18) \text {, antidepressants } \\
(n=2), \text { proton-pump } \\
\text { inhibitors }(n=9)\end{array}$ & \\
\hline
\end{tabular}

${ }^{*}$ P-value (Mann-Whitney-test), ${ }^{* *}(\mathrm{p}<0.01)$; ESA erythropoiesis-stimulating agent, CKD chronic kidney disease, HD hemodialysis, HDF online hemodiafiltration, CAPD continuous ambulatory peritoneal dialysis, APD automated peritoneal dialysis.

wavelength of $488 \mathrm{~nm}$ and an emission wavelength of $530 \mathrm{~nm}$ on a FACS Calibur. Subsequently, the geomean of the $\mathrm{Ca}^{2+}$ dependent fluorescence was determined.

\section{Reticulocyte count}

For determination of the reticulocyte count, heparinized whole blood $(2 \mu \mathrm{l})$ was added to $500 \mu \mathrm{l}$ Retic-COUNT $®$ (thiazole orange) reagent from Becton Dickinson. Samples were stained for $30 \mathrm{~min}$ at room temperature in the dark and flow cytometry was performed according to the manufacturer's instructions. Forward scatter (FSC), side scatter (SSC) and thiazole orange-fluorescence intensity (in FL-1) of the blood cells were determined. The number of Retic-COUNT positive reticulocytes was expressed as the percentage of the total gated erythrocyte population. Gating of erythrocytes was achieved by analysis of FSC vs. SSC dot plots using CellQuest software. 


\section{Kidney Blood Pressure Research}

Reactive oxygen species (ROS)

Oxidative stress was determined utilizing 2',7'-dichlorodihydrofluorescein diacetate (DCFDA). A volume of $4 \mu \mathrm{l}$ erythrocytes was mixed in $1 \mathrm{ml}$ Ringer. From the resulting cell suspension, $150 \mu \mathrm{l}$ were centrifuged (1600 rpm for $3 \mathrm{~min}$ at RT). Cells were stained with DCFDA (10 $\mu \mathrm{M}$; Sigma, Schnelldorf, Germany) in Ringer solution at $37^{\circ} \mathrm{C}$ for $30 \mathrm{~min}$ and then washed three times in $150 \mu \mathrm{l}$ Ringer solution. The DCFDA-loaded erythrocytes were resuspended in $200 \mu \mathrm{l}$ Ringer solution and ROS-dependent fluorescence intensity was measured in FL-1 channel at an excitation wavelength of $488 \mathrm{~nm}$ and an emission wavelength of $530 \mathrm{~nm}$ on a FACS Calibur. Afterwards, the geomean of the ROS-dependent fluorescence was determined.

Ceramide abundance

To determine ceramide abundance, a monoclonal antibody-based assay was used. Four $\mu$ l erythrocytes were mixed in $1 \mathrm{ml}$ Ringer. From the resulting cell suspension, $100 \mu \mathrm{l}$ were centrifuged ( $1600 \mathrm{rpm}$ for $3 \mathrm{~min}$ at RT) and the erythrocytes were pelleted. Subsequently, cells were stained for $1 \mathrm{~h}$ at $37^{\circ} \mathrm{C}$ with $1 \mu \mathrm{g} / \mathrm{ml}$ anti-ceramide antibody (1:10 dilution; clone MID 15B4; Alexis, Grünberg, Germany) in phosphate-buffered saline (PBS) containing $0.1 \%$ bovine serum albumin (BSA). After two washing steps with $100 \mu \mathrm{l}$ PBS-BSA, cells were stained for $30 \mathrm{~min}$ with polyclonal fluorescein-isothiocyanate (FITC)-conjugated goat anti-mouse IgG and IgM specific antibody (1:50 dilution; BD Pharmingen, Hamburg, Germany) in PBS-BSA. Unbound secondary antibody was removed by repeated washing with $50 \mu \mathrm{l}$ PBS-BSA. The samples were resuspended in $200 \mu \mathrm{l} \mathrm{PBS}$-BSA and then analyzed in FL-1 channel by flow cytometry at an excitation wavelength of $488 \mathrm{~nm}$ and an emission wavelength of $530 \mathrm{~nm}$ on a FACS Calibur. Finally, the geomean of the ceramide dependent fluorescence was determined.

\section{Statistics}

Data are expressed as median with interquartile range (IQR, $25^{\text {th }}-75^{\text {th }}$ percentile). Mann-Whitney test or One-way-ANOVA-test with Tukey's test as post-test were performed as appropriate to determine statistical significance between the two or three groups, respectively, using GraphPad Prism version 6.00 for Windows, GraphPad Software, La Jolla California USA. For all correlations, Spearman nonparametric analysis was used. $\mathrm{n}$ denotes the number of individuals. $p<0.05$ was considered significant.

\section{Results}

The present study explored whether eryptosis is stimulated in patients with endstage renal disease (ESRD) and under peritoneal dialysis (PD). Comparison was made to healthy individuals and ESRD patients under treatment with hemodialysis (HD). Eryptotic erythrocytes exposing phosphatidylserine at their surface were identified utilizing annexinV-binding. As illustrated in Fig. 1, the percentage of annexin V-binding erythrocytes was significantly higher in patients with ESRD under either PD or HD treatment than in healthy volunteers. The percentage of annexin V-binding erythrocytes was significantly higher in patients treated with PD than in patients treated with HD. As illustrated in Fig. 2, a significant correlation was observed in PD patients between volume of the dialysate and the percentage of annexin V-binding erythrocytes.

Forward scatter was taken as a measure of cell volume. Forward scatter was not significantly different between healthy individuals (508.1 [497.1; 521.4], $\mathrm{n}=38$ ), patients on HD treatment (522.9 [507.6; 553.2] $\mathrm{n}=18$ ) and patients on PD treatment (518.2 [492.8; 545.8], $\mathrm{n}=22$ ).

Further experiments were performed in order to identify cellular mechanisms underlying eryptosis in ESRD patients. A powerful stimulator is an increase in erythrocyte $\mathrm{Ca}^{2+}$ concentration $\left(\left[\mathrm{Ca}^{2+}\right]_{\mathrm{i}}\right)$. Fluo3 fluorescence was thus employed to estimate $\left[\mathrm{Ca}^{2+}\right]_{\mathrm{i}}$. As a result, Fluo3 fluorescence tended to be slightly higher in patients on HD treatment (20.78 [17.59; 24.26]), $\mathrm{n}=18$ ) and patients on PD treatment (19.50 [15.62; 24.69], $\mathrm{n}=22)$ ) than in healthy individuals (19.93 [18.44; 20.59], $\mathrm{n}=38)$ ), a difference, however, not reaching statistical significance.

Triggers of eryptosis include oxdative stress, which is enhanced in ESRD [17]. The abundance of reactive oxygen species (ROS) was thus determined utilizing 


\section{Kidney \\ Blood Pressure \\ Research}

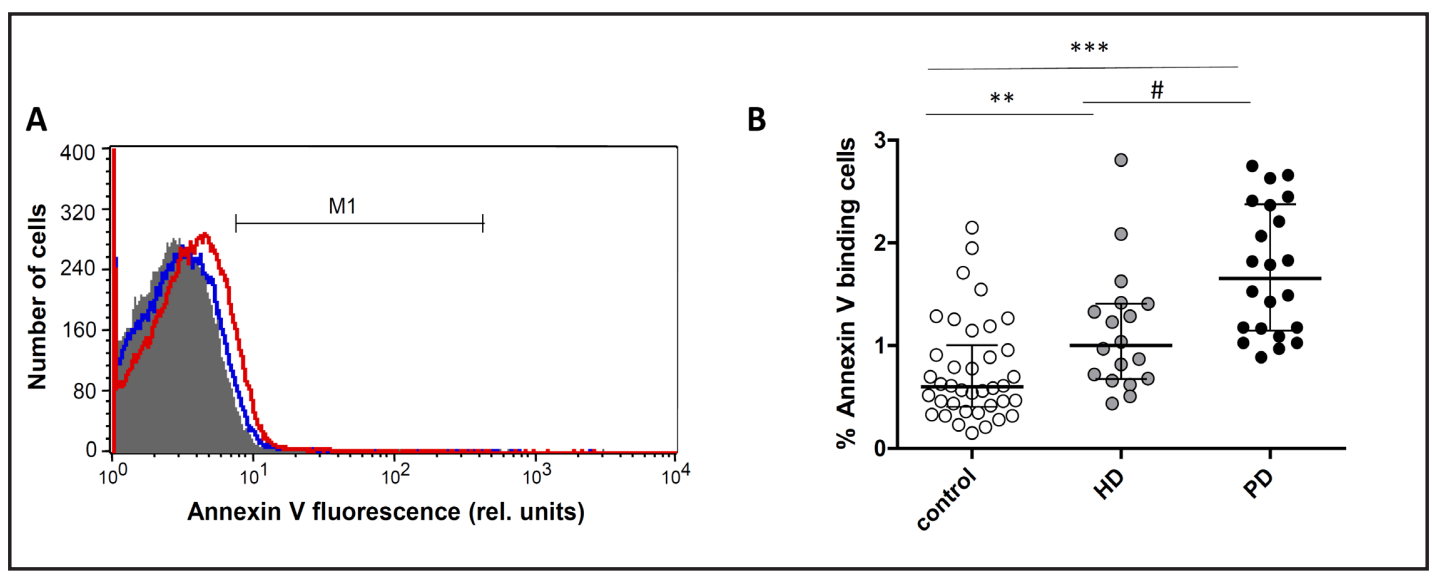

Fig. 1. Phosphatidylserine-exposing erythrocytes in freshly drawn blood from HD patients, PD patients and healthy volunteers. A. Original representative histogram of annexin V binding of erythrocytes in freshly drawn blood from healthy volunteers (grey shadow), from patients on hemodialysis (blue line) and from patients on peritoneal dialysis (red line). M1 indicates the annexin V fluorescence defining the percentage of annexin $\mathrm{V}$ binding erythrocytes. B. Individual values and median with interquartile range (IQR, $25^{\text {th }}$ $75^{\text {th }}$ percentile) of the percentage of annexin V-binding erythrocytes in freshly drawn blood from healthy volunteers (control, white circles), from patients on hemodialysis (HD, grey circles) and from patients on peritoneal dialysis (PD, black circles). ${ }^{* *}(p<0.01),{ }^{* * *}(p<0.001)$ indicate significant difference from healthy volunteers, $\#(p<0.05)$ indicates significant difference between HD and PD (ANOVA).

Fig. 2. Phosphatidylserine-exposing erythrocytes as a function of dialysate volume in PD. Percentage of annexin V-binding of erythrocytes in freshly drawn blood from patients on peritoneal dialysis as a function of dialysate volume ( $p=0.0261$, $\left.\mathrm{R}^{2}=0.2241\right) *{ }^{*}(p<0.05)$ indicates significant correlation.

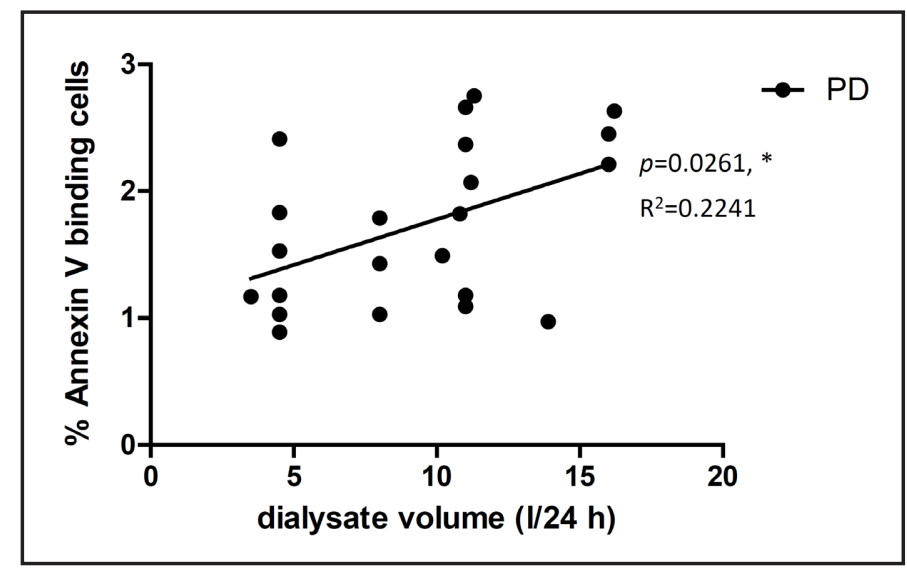

2',7'-dichlorodihydrofluorescein diacetate (DCFDA) fluorescence. As shown in Fig. 3, DCFDAfluorescence was significantly higher in erythrocytes from both, HD patients and PD patients than in erythrocytes from healthy individuals. No significant difference was observed between erythrocytes from HD patients and erythrocytes from PD patients.

A further known trigger of eryptosis is ceramide, which sensitizes erythrocytes to the effects of cytosolic $\mathrm{Ca}^{2+}$. Thus, ceramide abundance was determined by FITC-labeled anticeramide antibodies. As illustrated in Fig. 4, ceramide abundance was significantly higher in erythrocytes from both, HD patients and PD patients than in erythrocytes from healthy individuals. Again, no significant difference was observed between erythrocytes from HD patients and erythrocytes from PD patients.

To correct anemia, ESRD patients are treated with erythropoietin or other erythropoiesisstimulating agents (ESA). The rate of effective stimulation of erythropoiesis is reflected by the number of reticulocytes. As illustrated in Fig. 5, the reticulocyte number was higher in blood of both HD and PD patients than in healthy individuals, a difference reaching statistical significance in HD patients. Thus, the ESA treatment apparently rather over-compensated 


\section{Kidney Blood Pressure Research}

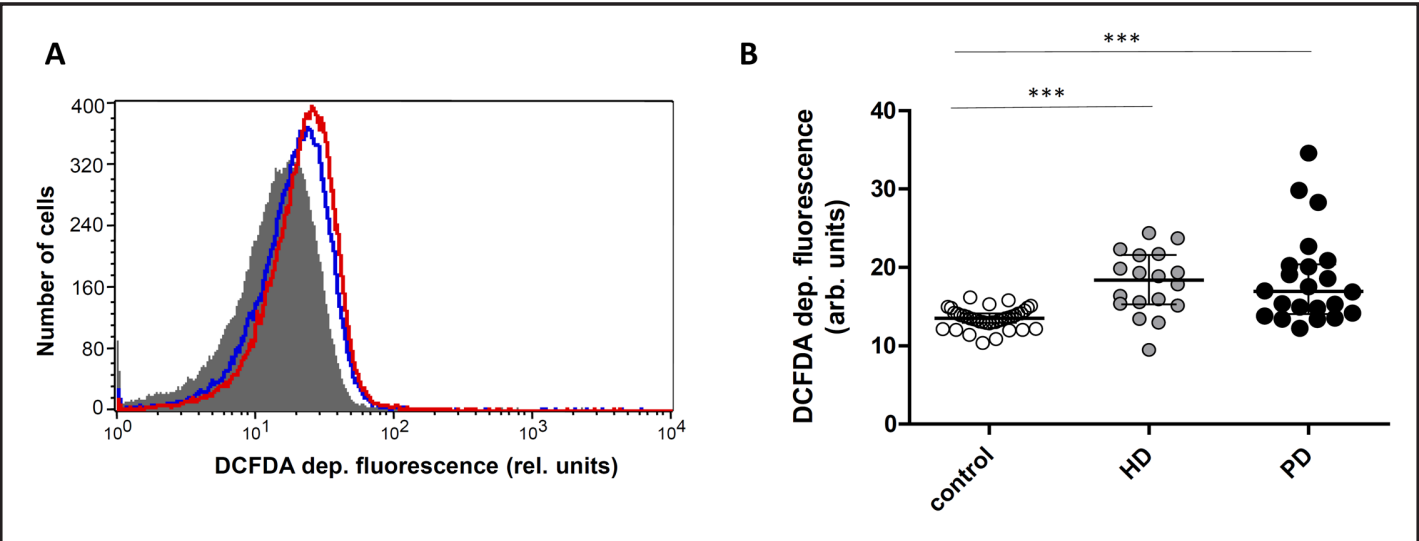

Fig. 3. Reactive oxygen species in freshly drawn blood from HD patients, PD patients and healthy volunteers. A. Original representative histogram of DCFDA dep. fluorescence of erythrocytes in freshly drawn blood from healthy volunteers (grey shadow), from patients on hemodialysis (blue line) and from patients on peritoneal dialysis (red line). B. Individual values and median with interquartile range (IQR, $25^{\text {th }}-75^{\text {th }}$ percentile) of the DCFDA fluorescence in freshly drawn erythrocytes from healthy volunteers (control, white circles), from patients on hemodialysis (HD, grey circles) and from patients on peritoneal dialysis (PD, black circles). ${ }^{* * *}(p<0.001)$ indicates significant difference from healthy volunteers (ANOVA).

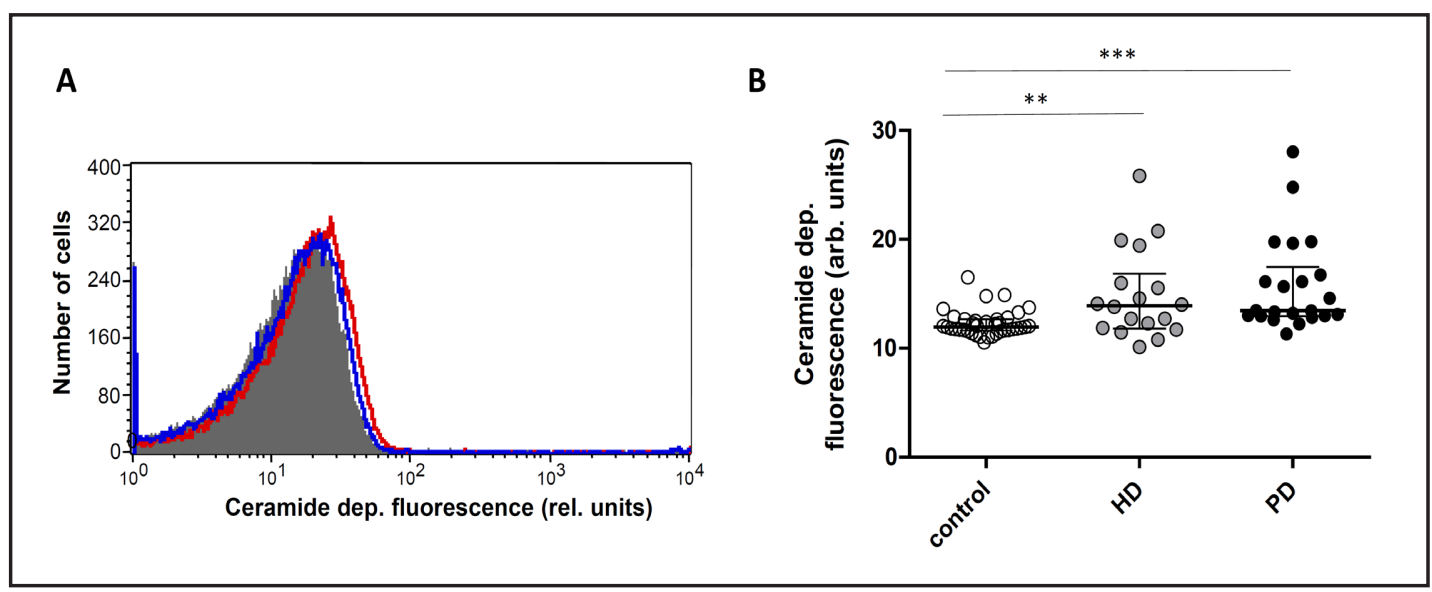

Fig. 4. Ceramide abundance in freshly drawn blood from HD patients, PD patients and healthy volunteers. A. Original representative histogram of ceramide dep. fluorescence of erythrocytes in freshly drawn blood from healthy volunteers (grey shadow), from patients on hemodialysis (blue line) and from patients on peritoneal dialysis (red line). B. Individual values and median with interquartile range (IQR, $25^{\text {th }}-75^{\text {th }}$ percentile) of the ceramide abundance in freshly drawn erythrocytes from healthy volunteers (control, white circles), from patients on hemodialysis (HD, grey circles) and from patients on peritoneal dialysis (PD, black circles). ${ }^{* * *}(p<0.001)$ indicates significant difference from healthy volunteers (ANOVA).

the lack of endogenous erythropoietin. The dosage of erythropoietin provided was similar in patients on HD treatment $(3125$ [401; 6000], $\mathrm{n}=18)$ and patients on PD treatment (4583 [1114; 6579]; $\mathrm{n}=22$ ).

Several correlations were calculated in order to disclose the relationships between erythropoietin dosage, reticulocyte numbers, blood hemoglobin concentration and eryptosis. The dosage of erythropoietin was adjusted to the plasma hemoglobin concentration, i.e. the dosage was increased in patients with severe anemia leading to a negative correlation between blood hemoglobin concentration and dosage of erythropoietin treatment (Fig. 6A). 


\section{Kidney \\ Blood Pressure \\ Research}
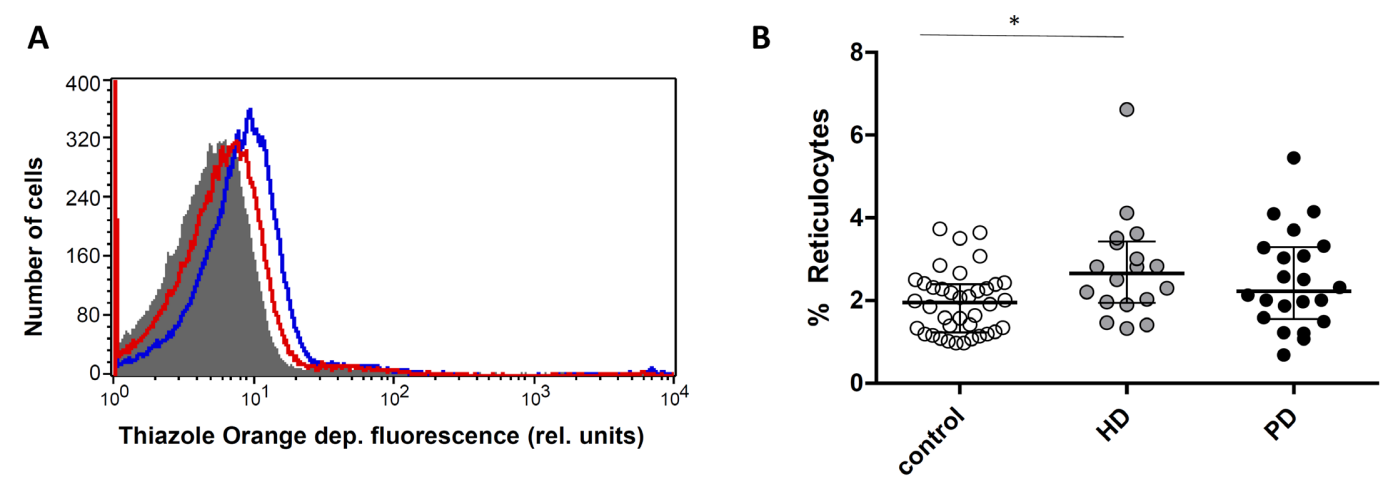

Fig. 5. Reticulocyte count in freshly drawn blood from HD patients, PD patients and healthy volunteers. A. Original representative histogram of Thiazole Orange fluorescence of erythrocytes in freshly drawn blood from healthy volunteers (grey shadow), from patients on hemodialysis (blue line) and from patients on peritoneal dialysis (red line). B. Individual values and median with interquartile range (IQR, $25^{\text {th }}-75^{\text {th }}$ percentile) of the percentage of reticulocytes in freshly drawn blood from healthy volunteers (control, white circles), from patients on hemodialysis (HD, grey circles) and from patients on peritoneal dialysis (PD, black circles). ${ }^{*}(p<0.05)$ indicates significant difference from healthy volunteers (ANOVA).

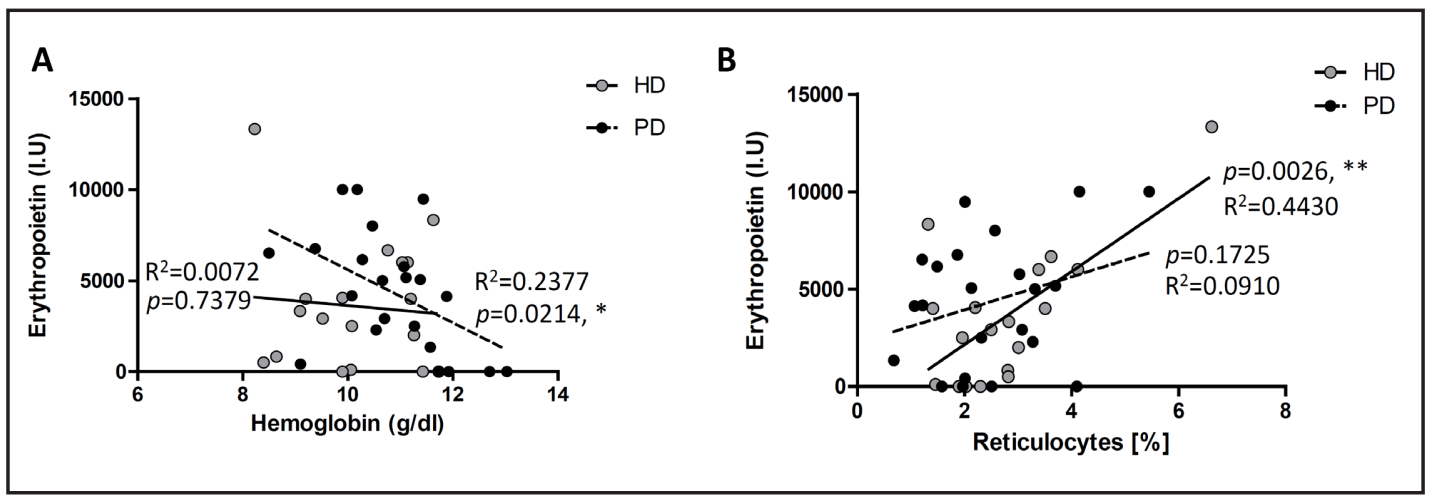

Fig. 6. The dosage of erythropoietin as a function of blood hemoglobin concentration and reticulocyte number in HD and PD patients. A. The dosage of erythropoietin as a function of hemoglobin concentration in freshly drawn blood from patients on hemodialysis (HD) ( $\left.p=0.7379, \mathrm{R}^{2}=0.0072\right)$ and peritoneal dialysis (PD) $\left(p=0.0214, \mathrm{R}^{2}=0.2377\right){ }^{*}(p<0.05)$ indicates significant correlation. $\mathrm{B}$. The dosage of erythropoietin as a function of reticulocyte number in freshly drawn blood from patients on hemodialysis (HD) ( $p=0.0026$, $\left.\mathrm{R}^{2}=0.4430\right)$ and peritoneal dialysis (PD) $\left(p=0.1725, \mathrm{R}^{2}=0.0910\right) .{ }^{* *}(p<0.01)$ indicates significant correlation.

The correlation reached statistical significance in PD patients. A positive correlation was observed between dosage of erythropoietin treatment and reticulocyte number (Fig. 6B). The correlation reached statistical significance in HD patients.

The percentage of annexin-V-binding erythrocytes was positively correlated with the reticulocyte number (Fig. 7A) and with erythropoietin dosage (Fig. 7B). The correlations were statistically significant for both HD patients and PD patients.

\section{Discussion}

The present study confirms a previous report [18] showing enhanced percentage of phosphatidylserine-exposing erythrocytes reflecting eryptosis in patients with end-stage renal 


\section{Kidney Blood Pressure Research}
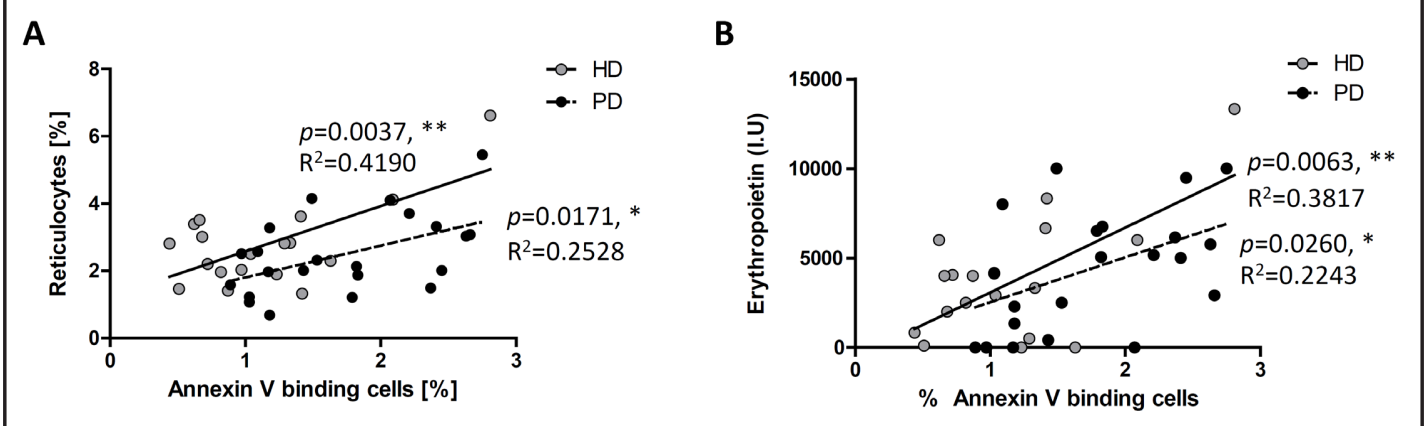

Fig. 7. Reticulocyte number and erythropoietin dosage as a function of the percentage of annexin-V-binding erythrocytes in HD and PD patients. A. The percentage of reticulocytes in freshly drawn blood from patients on hemodialysis (HD) ( $\left.p=0.0037, \mathrm{R}^{2}=0.4190\right)$ and peritoneal dialysis (PD) $\left(p=0.0171, \mathrm{R}^{2}=0.2528\right)$ as a function of the percentage of annexin V-binding erythrocytes. ${ }^{*}(p<0.05)$ and ${ }^{* *}(p<0.01)$ indicate significant correlation. B. The dosage of erythropoietin administration as a function of the percentage of annexin V-binding erythrocytes in freshly drawn blood from patients on hemodialysis (HD) $\left(p=0.0063, \mathrm{R}^{2}=0.3817\right)$ and peritoneal dialysis (PD) $\left(p=0.0260, \mathrm{R}^{2}=0.2243\right) .{ }^{*}(p<0.05)$ and ${ }^{* *}(p<0.01)$ indicate significant correlation.

disease (ESRD) treated with hemodialysis (HD). More importantly, the present study reveals that eryptosis is more prominent in patients on peritoneal dialysis (PD) than in patients on HD. In patients on PD, the percentage of phosphatidylserine-exposing erythrocytes is correlated with the dialysate volume. Possibly, glucose-based components of the dialysate contribute to the stimulation of eryptosis. A previous study revealed that eryptosis in ESRD patients on HD is at least partially stimulated by a plasma borne component [18], which could be an uremic toxin, such as vanadate [20], acrolein [26], methylglyoxal [20] and/or phosphate [27]. Eryptosis is further stimulated by a variety of clinical conditions [18, 26-36] and by a myriad of xenobiotics [32, 37-79], which may further aggravate the anemia of ESRD.

Similar to what has been observed earlier in HD patients [18], eryptosis in HD patients is paralled by oxidative stress and enhanced ceramide formation, which are both well known triggers of eryptosis [20]. In an earlier study, eryptosis was shown to be paralleled by increase of cytosolic $\mathrm{Ca}^{2+}$-concentration $\left(\left[\mathrm{Ca}^{2+}\right]_{\mathrm{i}}\right)[18]$. In the present study $\left[\mathrm{Ca}^{2+}\right]_{\mathrm{i}}$ similarly tended to be higher in erythrocytes from HD patients than in erythrocytes from healthy individuals, a difference, however, not reaching statistical significance. Needless to say, the present observations do not rule out the contribution of further cellular mechanisms to the stimulation of eryptosis in ESRD.

The percentage of phosphatidylserine-exposing erythrocytes was twice as high in freshly drawn blood from ESRD patients on PD as in blood from healthy volunteers. In view of the rapid clearance of phosphatidylserine-exposing erythrocytes from circulating blood [20], a doubling of phosphatidylserine-exposing erythrocytes in circulating blood points to a decrease of erythrocyte life span to half [80]. At constant erythropoiesis, a decrease of erythrocyte life span to half should reduce the number of circulating erythrocytes by $50 \%$. The accelerated eryptosis thus explains the persistance of anemia despite adequate replacement of erythropoietin and normalization of erythropoiesis in ESRD patients.

In addition to its impact on anemia, eryptosis may interfere with microcirculation, as phosphatidylserine-exposingerythrocytes adhere to the vascularwall [81]. Phosphatidylserineexposing erythrocytes further stimulate blood clotting [20]. Excessive eryptosis could thus contribute to the known increase of cardiovascular risk in uremic patients [82, 83]. Attempts to normalize blood count in ESRD patients by stimulation of erythropoiesis were expected to increase erythrocyte turnover and thus the number of phosphatidylserine-exposing erythrocytes in circulating blood. Along those lines, the susceptibility of erythrocytes to triggers of eryptosis is increased by chronically enhanced erythropoietin levels [84] and excessive eryptosis could, at least in theory, contribute to the untoward side effects following 


\section{Kidney Bloód Pressure Research}

uncritical use of erythropoietin or other erythropoiesis-stimulating agents $[5,83,85,86]$. In view of our observations we advocate a therapeutic approach combining inhibition of eryptosis and replacement of erythropoietin.

\section{Conclusion}

Similar to patients on HD, patients on PD suffer from marked stimulation of eryptosis leading to an approximate doubling of suicidal erythrocytes. Eryptosis is paralleled by oxidative stress and enhanced ceramide abundance. The enhanced eryptosis presumably leads to accelerated erythrocyte loss and thus substantially contributes to the anemia of the patients.

\section{Disclosure Statement}

The authors confirm that there are no conflicts of interest to be stated.

\section{Acknowledgements}

The study was supported by the Deutsche Forschungsgemeinschaft (grant to FL).

\section{References}

1 Atkinson MA, Furth SL: Anemia in children with chronic kidney disease. Nat Rev Nephrol 2011;7:635-641.

2 Parfrey PS: Critical appraisal of randomized controlled trials of anemia correction in patients with renal failure. Curr Opin Nephrol Hypertens 2011;20:177-181.

3 Fishbane S, Nissenson AR: Anemia management in chronic kidney disease. Kidney Int Suppl 2010, DOI 10.1038/ki.2010.188.

4 Adamson JW: Hyporesponsiveness to erythropoiesis stimulating agents in chronic kidney disease: the many faces of inflammation. Adv Chronic Kidney Dis 2009;16:76-82.

5 Besarab A, Frinak S, Yee J: What is so bad about a hemoglobin level of 12 to $13 \mathrm{~g} / \mathrm{dL}$ for chronic kidney disease patients anyway? Adv Chronic Kidney Dis 2009;16:131-142.

6 Macdougall IC, Ashenden M: Current and upcoming erythropoiesis-stimulating agents, iron products, and other novel anemia medications. Adv Chronic Kidney Dis 2009;16:117-130.

7 Wish JB: Past, present, and future of chronic kidney disease anemia management in the United States. Adv Chronic Kidney Dis 2009;16:101-108.

8 Yee J, Zasuwa G, Frinak S, Besarab A: Hemoglobin variability and hyporesponsiveness: much ado about something or nothing? Adv Chronic Kidney Dis 2009;16:83-93.

9 Artunc F, Risler T: Serum erythropoietin concentrations and responses to anaemia in patients with or without chronic kidney disease. Nephrology Dialysis Transplantation 2007;22:2900-2908.

10 Yang M, Fox CH, Vassalotti J, Choi M: Complications of progression of CKD. Adv Chronic Kidney Dis 2011;18:400-405.

11 Dmitrieva O, de Lusignan S, Macdougall IC, Gallagher H, Tomson C, Harris K, Desombre T, Goldsmith D: Association of anaemia in primary care patients with chronic kidney disease: cross sectional study of quality improvement in chronic kidney disease (QICKD) trial data. BMC Nephrol 2013;14:24.

12 Attanasio P, Ronco C, Anker SD, Cicoira M, von Haehling S: Role of iron deficiency and anemia in cardiorenal syndromes. Semin Nephrol 2012;32:57-62.

13 Besarab A, Coyne DW: Iron supplementation to treat anemia in patients with chronic kidney disease. Nat Rev Nephrol 2010;6:699-710.

14 Kwack C, Balakrishnan VS: Managing erythropoietin hyporesponsiveness. Semin Dial 2006;19:146-151.

15 Kovesdy CP: Iron and clinical outcomes in dialysis and non-dialysis-dependent chronic kidney disease patients. Adv Chronic Kidney Dis 2009;16:109-116. 


\section{Kidney \\ Blood Pressure Research}

16 Myssina S, Huber SM, Birka C, Lang PA, Lang KS, Friedrich B, Risler T, Wieder T, Lang F: Inhibition of erythrocyte cation channels by erythropoietin. J Am Soc Nephrol 2003;14:2750-2757.

17 Popolo A, Autore G, Pinto A, Marzocco S: Oxidative stress in patients with cardiovascular disease and chronic renal failure. Free Radic Res 2013;47:346-356.

18 Abed M, Artunc F, Alzoubi K, Honisch S, Baumann D, Foller M, Lang F: Suicidal erythrocyte death in endstage renal disease. J Mol Med (Berl) 2014;92:871-879.

19 Vos FE, Schollum JB, Coulter CV, Doyle TC, Duffull SB, Walker RJ: Red blood cell survival in long-term dialysis patients. Am J Kidney Dis 2011;58:591-598.

20 Lang E, Qadri SM, Lang F: Killing me softly - suicidal erythrocyte death. Int J Biochem Cell Biol 2012;44:1236-1243.

21 Nguyen DB, Wagner-Britz L, Maia S, Steffen P, Wagner C, Kaestner L, Bernhardt I: Regulation of phosphatidylserine exposure in red blood cells. Cell Physiol Biochem 2011;28:847-856.

22 Huang YX, Tuo WW, Wang D, Kang LL, Chen XY, Luo M: Restoring the youth of aged red blood cells and extending their lifespan in circulation by remodelling membrane sialic acid. J Cell Mol Med 2016;20:294301.

23 Foller M, Mahmud H, Gu S, Kucherenko Y, Gehring EM, Shumilina E, Floride E, Sprengel R, Lang F: Modulation of suicidal erythrocyte cation channels by an AMPA antagonist. J Cell Mol Med 2009;13:36803686.

24 Obrador GT, Roberts T, St Peter WL, Frazier E, Pereira BJ, Collins AJ: Trends in anemia at initiation of dialysis in the United States. Kidney Int 2001;60:1875-1884.

25 Coronel F, Herrero JA, Montenegro J, Fernandez C, Gandara A, Conesa J, Rivera MT, Torrente J, Portoles J, Gomez-Martino JR: Erythropoietin requirements: a comparative multicenter study between peritoneal dialysis and hemodialysis. J Nephrol 2003;16:697-702.

26 Ahmed M, Langer H, Abed M, Voelkl J, Lang F: The Uremic Toxin Acrolein Promotes Suicidal Erythrocyte Death. Kidney Blood Press Res 2013;37:158-167

27 Voelkl J, Alzoubi K, Mamar AK, Ahmed MS, Abed M, Lang F: Stimulation of suicidal erythrocyte death by increased extracellular phosphate concentrations. Kidney Blood Press Res 2013;38:42-51.

28 Abed M, Feger M, Alzoubi K, Pakladok T, Frauenfeld L, Geiger C, Towhid ST, Lang F: Sensitization of erythrocytes to suicidal erythrocyte death following water deprivation. Kidney Blood Press Res 2013;37:567-578.

29 Calderon-Salinas JV, Munoz-Reyes EG, Guerrero-Romero JF, Rodriguez-Moran M, Bracho-Riquelme RL, Carrera-Gracia MA, Quintanar-Escorza MA: Eryptosis and oxidative damage in type 2 diabetic mellitus patients with chronic kidney disease. Mol Cell Biochem 2011;357:171-179.

30 Kempe DS, Akel A, Lang PA, Hermle T, Biswas R, Muresanu J, Friedrich B, Dreischer P, Wolz C, Schumacher U, Peschel A, Gotz F, Doring G, Wieder T, Gulbins E, Lang F: Suicidal erythrocyte death in sepsis. J Mol Med (Berl) 2007;85:273-281.

31 Lang E, Gatidis S, Freise NF, Bock H, Kubitz R, Lauermann C, Orth HM, Klindt C, Schuier M, Keitel V, Reich M, Liu G, Schmidt S, Xu HC, Qadri SM, Herebian D, Pandyra AA, Mayatepek E, Gulbins E, Lang F, Haussinger D, Lang KS, Foller M, Lang PA: Conjugated bilirubin triggers anemia by inducing erythrocyte death. Hepatology 2015;61:275-284.

32 Lang E, Lang F: Mechanisms and pathophysiological significance of eryptosis, the suicidal erythrocyte death. Semin Cell Dev Biol 2015;39:35-42.

33 Lang PA, Beringer O, Nicolay JP, Amon O, Kempe DS, Hermle T, Attanasio P, Akel A, Schafer R, Friedrich B, Risler T, Baur M, Olbricht CJ, Zimmerhackl LB, Zipfel PF, Wieder T, Lang F: Suicidal death of erythrocytes in recurrent hemolytic uremic syndrome. J Mol Med (Berl) 2006;84:378-388.

34 Lang PA, Schenck M, Nicolay JP, Becker JU, Kempe DS, Lupescu A, Koka S, Eisele K, Klarl BA, Rubben H, Schmid KW, Mann K, Hildenbrand S, Hefter H, Huber SM, Wieder T, Erhardt A, Haussinger D, Gulbins E, Lang F: Liver cell death and anemia in Wilson disease involve acid sphingomyelinase and ceramide. Nat Med 2007;13:164-170.

35 Nicolay JP, Schneider J, Niemoeller OM, Artunc F, Portero-Otin M, Haik G, Jr., Thornalley PJ, Schleicher E, Wieder T, Lang F: Stimulation of suicidal erythrocyte death by methylglyoxal. Cell Physiol Biochem 2006;18:223-232.

36 Polak-Jonkisz D, Purzyc L: Ca(2+) influx versus efflux during eryptosis in uremic erythrocytes. Blood Purif 2012;34:209-210; author reply 210. 


\section{Kidney \\ Blood Pressure Research}

37 Alzoubi K, Calabro S, Bissinger R, Abed M, Faggio C, Lang F: Stimulation of suicidal erythrocyte death by artesunate. Cell Physiol Biochem 2014;34:2232-2244.

38 Alzoubi K, Egler J, Abed M, Lang F: Enhanced eryptosis following auranofin exposure. Cell Physiol Biochem 2015;37:1018-1028.

39 Arnold M, Bissinger R, Lang F: Mitoxantrone-induced suicidal erythrocyte death. Cell Physiol Biochem 2014;34:1756-1767.

40 Arnold M, Lang E, Modicano P, Bissinger R, Faggio C, Abed M, Lang F: Effect of nitazoxanide on erythrocytes. Basic Clin Pharmacol Toxicol 2014;114:421-426.

41 Bissinger R, Barking S, Alzoubi K, Liu G, Liu G, Lang F: Stimulation of Suicidal Erythrocyte Death by the Antimalarial Drug Mefloquine. Cell Physiol Biochem 2015;36:1395-1405.

42 Bissinger R, Bouguerra G, Al Mamun Bhuyan A, Waibel S, Abbes S, Lang F: Efavirenz Induced Suicidal Death of Human Erythrocytes. Cell Physiol Biochem 2015;37:2496-2507.

43 Bissinger R, Bouguerra G, Stockinger K, Abbes S, Lang F: Triggering of Suicidal Erythrocyte Death by Topotecan. Cell Physiol Biochem 2015;37:1607-1618.

44 Bissinger R, Fischer S, Jilani K, Lang F: Stimulation of erythrocyte death by phloretin. Cell Physiol Biochem 2014;34:2256-2265.

45 Bissinger R, Lupescu A, Zelenak C, Jilani K, Lang F: Stimulation of eryptosis by cryptotanshinone. Cell Physiol Biochem 2014;34:432-442.

46 Bissinger R, Waibel S, Bouguerra G, Al Mamun Bhuyan A, Abbes S, Lang F: Enhanced Eryptosis Following Exposure to Lopinavir. Cell Physiol Biochem 2015;37:2486-2495.

47 Bouguerra G, Aljanadi O, Bissinger R, Abbes S, Lang F: Embelin-Induced Phosphatidylserine Translocation in the Erythrocyte Cell Membrane. Cell Physiol Biochem 2015;37:1629-1640.

48 Bouguerra G, Bissinger R, Abbes S, Lang F: Stimulation of Eryptosis by Narasin. Cell Physiol Biochem 2015;37:1807-1816.

49 Bouguerra G, Bissinger R, Abbes S, Lang F: Zopolrestat Induced Suicidal Death of Human Erythrocytes. Cell Physiol Biochem 2015;37:1537-1546.

50 Briglia M, Calabro S, Signoretto E, Alzoubi K, Laufer S, Faggio C, Lang F: Fucoxanthin Induced Suicidal Death of Human Erythrocytes. Cell Physiol Biochem 2015;37:2464-2475.

51 Briglia M, Fazio A, Faggio C, Lang F: Triggering of Suicidal Erythrocyte Death by Zosuquidar. Cell Physiol Biochem 2015;37:2355-2365.

52 Briglia M, Fazio A, Faggio C, Laufer S, Alzoubi K, Lang F: Triggering of Suicidal Erythrocyte Death by Ruxolitinib. Cell Physiol Biochem 2015;37:768-778.

53 Briglia M, Fazio A, Signoretto E, Faggio C, Lang F: Edelfosine Induced Suicidal Death of Human Erythrocytes. Cell Physiol Biochem 2015;37:2221-2230.

54 Calabro S, Alzoubi K, Faggio C, Laufer S, Lang F: Triggering of Suicidal Erythrocyte Death Following Boswellic Acid Exposure. Cell Physiol Biochem 2015;37:131-142.

55 Egler J, Lang F: Licochalcone A Induced Suicidal Death of Human Erythrocytes. Cell Physiol Biochem 2015;37:2060-2070.

56 Faggio C, Alzoubi K, Calabro S, Lang F: Stimulation of suicidal erythrocyte death by PRIMA-1. Cell Physiol Biochem 2015;35:529-540.

57 Fazio A, Briglia M, Faggio C, Alzoubi K, Lang F: Stimulation of Suicidal Erythrocyte Death by Garcinol. Cell Physiol Biochem 2015;37:805-815.

58 Fazio A, Briglia M, Faggio C, Alzoubi K, Lang F: Oxaliplatin Induced Suicidal Death of Human Erythrocytes. Cell Physiol Biochem 2015;37:2393-2404.

59 Jacobi J, Lang E, Bissinger R, Frauenfeld L, Modicano P, Faggio C, Abed M, Lang F: Stimulation of erythrocyte cell membrane scrambling by mitotane. Cell Physiol Biochem 2014;33:1516-1526.

60 Lang E, Jilani K, Bissinger R, Rexhepaj R, Zelenak C, Lupescu A, Lang F, Qadri SM: Vitamin D-Rich Diet in Mice Modulates Erythrocyte Survival. Kidney Blood Press Res 2015;40:403-412.

61 Lang E, Zelenak C, Eberhard M, Bissinger R, Rotte A, Ghashghaeinia M, Lupescu A, Lang F, Qadri SM: Impact of cyclin-dependent kinase CDK4 inhibition on eryptosis. Cell Physiol Biochem 2015;37:1178-1186.

62 Lupescu A, Bissinger R, Goebel T, Salker MS, Alzoubi K, Liu G, Chirigiu L, Mack AF, Qadri SM, Lang F: Enhanced suicidal erythrocyte death contributing to anemia in the elderly. Cell Physiol Biochem 2015;36:773-783.

63 Lupescu A, Bissinger R, Herrmann T, Oswald G, Jilani K, Lang F: Induction of suicidal erythrocyte death by novobiocin. Cell Physiol Biochem 2014;33:670-680. 


\section{Kidney \\ Blood Pressure Research}

64 Lupescu A, Bissinger R, Warsi J, Jilani K, Lang F: Stimulation of erythrocyte cell membrane scrambling by gedunin. Cell Physiol Biochem 2014;33:1838-1848.

65 Macczak A, Cyrkler M, Bukowska B, Michalowicz J: Eryptosis-inducing activity of bisphenol A and its analogs in human red blood cells (in vitro study). J Hazard Mater 2016;307:328-335.

66 Maellaro E, Leoncini S, Moretti D, Del Bello B, Tanganelli I, De Felice C, Ciccoli L: Erythrocyte caspase-3 activation and oxidative imbalance in erythrocytes and in plasma of type 2 diabetic patients. Acta Diabetol 2013;50:489-495.

67 Malik A, Bissinger R, Calabro S, Faggio C, Jilani K, Lang F: Aristolochic acid induced suicidal erythrocyte death. Kidney Blood Press Res 2014;39:408-419.

68 Officioso A, Alzoubi K, Lang F, Manna C: Hydroxytyrosol inhibits phosphatidylserine exposure and suicidal death induced by mercury in human erythrocytes: Possible involvement of the glutathione pathway. Food Chem Toxicol 2016;89:47-53.

69 Officioso A, Alzoubi K, Manna C, Lang F: Clofazimine Induced Suicidal Death of Human Erythrocytes. Cell Physiol Biochem 2015;37:331-341.

70 Officioso A, Manna C, Alzoubi K, Lang F: Bromfenvinphos induced suicidal death of human erythrocytes. Pestic Biochem Physiol 2016;126:58-63.

71 Oswald G, Alzoubi K, Abed M, Lang F: Stimulation of suicidal erythrocyte death by ribavirin. Basic Clin Pharmacol Toxicol 2014;114:311-317.

72 Pagano M, Faggio C: The use of erythrocyte fragility to assess xenobiotic cytotoxicity. Cell Biochem Funct 2015;33:351-355.

73 Peter T, Bissinger R, Enkel S, Alzoubi K, Oswald G, Lang F: Programmed erythrocyte death following in vitro Treosulfan treatment. Cell Physiol Biochem 2015;35:1372-1380.

74 Qadri SM, Donkor DA, Bhakta V, Eltringham-Smith LJ, Dwivedi DJ, Moore JC, Pepler L, Ivetic N, Nazi I, FoxRobichaud AE, Liaw PC, Sheffield WP: Phosphatidylserine externalization and procoagulant activation of erythrocytes induced by Pseudomonas aeruginosa virulence factor pyocyanin. J Cell Mol Med 2016;20:710720 .

75 Stockinger K, Bissinger R, Bouguerra G, Abbes S, Lang F: Enhanced Eryptosis Following Exposure to Carnosic Acid. Cell Physiol Biochem 2015;37:1779-1791.

76 Tesoriere L, Attanzio A, Allegra M, Cilla A, Gentile C, Livrea MA: Oxysterol mixture in hypercholesterolemiarelevant proportion causes oxidative stress-dependent eryptosis. Cell Physiol Biochem 2014;34:10751089.

77 Waibel S, Bissinger R, Bouguerra G, Abbes S, Lang F: Saquinavir Induced Suicidal Death of Human Erythrocytes. Cell Physiol Biochem 2015;37:1973-1982.

78 Zierle J, Bissinger R, Bouguerra G, Abbes S, Lang F: Triggering of Suicidal Erythrocyte Death by Regorafenib. Cell Physiol Biochem 2016;38:160-172.

79 Zierle J, Bissinger R, Egler J, Lang F: Lapatinib Induced Suicidal Death of Human Erythrocytes. Cell Physiol Biochem 2015;37:2275-2287.

80 Qadri SM, Mahmud H, Lang E, Gu S, Bobbala D, Zelenak C, Jilani K, Siegfried A, Foller M, Lang F: Enhanced suicidal erythrocyte death in mice carrying a loss-of-function mutation of the adenomatous polyposis coli gene. J Cell Mol Med 2012;16:1085-1093.

81 Borst O, Abed M, Alesutan I, Towhid ST, Qadri SM, Foller M, Gawaz M, Lang F: Dynamic adhesion of eryptotic erythrocytes to endothelial cells via CXCL16/SR-PSOX. Am J Physiol Cell Physiol 2012;302:C644-651.

82 Palmer SC, Navaneethan SD, Craig JC, Johnson DW, Tonelli M, Garg AX, Pellegrini F, Ravani P, Jardine M, Perkovic V, Graziano G, McGee R, Nicolucci A, Tognoni G, Strippoli GF: Meta-analysis: erythropoiesisstimulating agents in patients with chronic kidney disease. Ann Intern Med 2010;153:23-33.

83 Staude H, Jeske S, Schmitz K, Warncke G, Fischer DC: Cardiovascular risk and mineral bone disorder in patients with chronic kidney disease. Kidney Blood Press Res 2013;37:68-83.

84 Foller M, Kasinathan RS, Koka S, Huber SM, Schuler B, Vogel J, Gassmann M, Lang F: Enhanced susceptibility to suicidal death of erythrocytes from transgenic mice overexpressing erythropoietin. Am J Physiol Regul Integr Comp Physiol 2007;293:R1127-1134.

85 Singh AK: What is causing the mortality in treating the anemia of chronic kidney disease: erythropoietin dose or hemoglobin level? Curr Opin Nephrol Hypertens 2010;19:420-424.

86 Elliott J, Mishler D, Agarwal R: Hyporesponsiveness to erythropoietin: causes and management. Adv Chronic Kidney Dis 2009;16:94-100. 